\title{
The Lanternfly genus Polydictya (Hemiptera: Fulgoromorpha: Fulgoridae) from Sulawesi and neighbouring islands, with the description of three new species
}

\author{
Jérôme CONSTANT \\ Royal Belgian Institute of Natural Sciences, O.D. Phylogeny and Taxonomy, Entomology, \\ Vautier street 29, B-1000 Brussels, Belgium. \\ E-mail: jerome.constant@naturalsciences.be
}

urn:Isid:zoobank.org:author:6E6072A1-9415-4C8D-8E60-2504444DB290

\begin{abstract}
The species of the genus Polydictya Guérin-Méneville, 1844 from Sulawesi and adjacent islands are reviewed and three new species are described: P. bantimurung sp. nov. (Sulawesi), P. basirubra sp. nov. (Sulawesi, Wowoni and Buton) and P. pelengana sp. nov. (Peleng). An identification key for the 6 species recorded in the area is given. Habitus, detailed illustrations and a distribution map are provided for all species. The male genitalia of the three new species are illustrated and described, and the male genitalia of $P$. thanatos Chew Kea Foo, Porion \& Audibert, 2010 are figured and described for the first time. The genus Polydictya now contains 24 species.
\end{abstract}

Keywords. Indonesia, lanternbug, Fulgoroidea, Homoptera, planthopper.

Constant J. 2015. The Lanternfly genus Polydictya (Hemiptera: Fulgoromorpha: Fulgoridae) from Sulawesi and neighbouring islands, with the description of three new species. European Journal of Taxonomy 110: 1-19. http:// dx.doi.org/10.5852/ejt.2015.110

\section{Introduction}

The genus Polydictya was erected by Guérin-Méneville (1844) to accommodate one species, Eurybarchis (sic!) basalis Hope, 1843, described from Silhet (Myanmar) and mentioned from Penang Island (Malaysia) by Guérin-Méneville (1844). Species were progressively added to the genus (Bourgoin 2014).

The genus Thaumastodictya, described by Kirkaldy (1902) based on one species, T. krisna Kirkaldy, 1902 from Sri Lanka, was synonymized under Polydictya by Distant (1906a). Lallemand $(1959,1963)$, Nagai \& Porion (1996, 2004), Constant \& Pham (2008), Constant $(2009,2010)$ and Chew Kea Foo et al. (2010) more recently added new species and proposed nomenclatural changes within the genus.

The genus presently contains 21 species (Bourgoin 2014). It is distributed in the Oriental region: from Sri Lanka it extends over northern India, Thailand, Vietnam and southwards to Sulawesi and its adjacent islands. 
One species, $P$. crassa, was described from "South Celebes" (Distant 1906b). It was the only species known from Sulawesi until the recent descriptions of P. katsurakoae Nagai \& Porion, 1996 and P. thanatos Chew Kea Foo, Porion \& Audibert, 2010.

The study of recent material in the collections of BMNH, MNHL and RBINS led to the discovery of three new species which are here described, illustrated and keyed together with the three previously decribed ones.

\section{Materials and methods}

Type specimens of all species have been examined. The male genitalia were dissected as follows: the pygofer was cut from the abdomen of the softened specimen with a needle blade, then boiled for about one hour in a $10 \%$ solution of potassium hydroxide $(\mathrm{KOH})$. The phallic complex was dissected with a needle blade and all pieces examined in ethanol, the whole placed in glycerine for preservation. Observations were done with a Leica MZ8 stereo microscope. Pictures were taken with a Canon EOS 300 D camera with Sigma DG Macro lens and optimized with Adobe Photoshop CS3. The inflation of the phallus was not done due to the difficulty to obtain good and replicable results, and because it is not indispensable to separate the species in the genus Polydictya.

For the transcription of the labels of the types, the wording on each single label is limited by square brackets.

The measurements were taken as in Constant (2004) and the following abbreviations are used:

$\mathrm{BF}=$ breadth of the frons

$\mathrm{BTg}=$ breadth of the tegmen

$\mathrm{BV}=$ breadth of the vertex

$\mathrm{LF}=$ length of the frons

$\mathrm{LT}=$ total length

$\mathrm{LTg}=$ length of the tegmen

$\mathrm{LV}=$ length of the vertex

Acronyms used for the collections (name of the curator in parentheses):

$\mathrm{BMNH}=$ Natural History Museum, London, United Kingdom (M. Webb)

$\mathrm{EUM}=$ Ehime University Museum, Matsuyama, Japan (H. Yoshitomi)

MHNL = Muséum d'Histoire naturelle de Lyon, France (H. Labrique, J. Clary and C. Audibert)

MNHN = Museum national d'Histoire naturelle, Paris, France (T. Bourgoin and A. Soulier)

RBINS $=$ Royal Belgian Institute of Natural Sciences, Brussels, Belgium (W. Dekoninck)

\section{Results}

Class Hexapoda Blainville, 1816

Order Hemiptera Linnaeus, 1758

Suborder Auchenorrhyncha Duméril, 1806

Infraorder Fulgoromorpha Evans, 1946

Superfamily Fulgoroidea Latreille, 1807

Family Fulgoridae Latreille, 1807 
Genus Polydictya Guérin-Méneville, 1844

Polydictya Guérin-Méneville, 1844: 358. Type species: Polydictya basalis (Hope, 1843) by monotypy. Thaumastodictya Kirkaldy, 1902: 307. Type species: Polydictya krisna Kirkaldy, 1902 by original designation (junior synonym of Polydictya pantherina Gerstaecker, 1895, see Nagai \& Porion 1996).

Polydictya - Walker 1851: 289 (list of species). - Stål 1866: 135 (key). - Atkinson 1885: 155 (described). — Distant 1888: 487 (compared to Myrilla Distant, 1888). — Karsch 1890: 63 (compared to Anecphora Karsch, 1890). — Gerstaecker 1895: 10 (compared to Holodictya Gerstaecker, 1895). Kirkaldy 1902: 307 (compared to Thaumastodictya Kirkaldy, 1902). — Melichar 1903: 71 (erroneous synonymy with Chalia Walker, 1858). — Distant 1906a: 199 (key to Oriental genera), 215 (described, senior synonym of Thaumastodictya). - Kirkaldy 1907: 59 (note on publication date). - Schmidt 1907: 113 (compared to Myrilla, copied from Distant 1888). - Jacobi 1910: 101 (compared to Coelodictya Jacobi, 1910). - Schmidt 1912: 71 (compared to Coelodictya and Holodictya, comments on species). — Lallemand 1963: 7 (key to genera), 14 (key to species). - Nagai \& Porion 1996: 13 (list of species, synonymies). - Constant \& Pham 2008 (notes). - Constant 2009 (notes, key to species with hind wings red basally). - Constant 2010 (notes).

Thaumastodictya - Melichar 1903: 71 (description). - Distant 1906a: 215 (junior synonym of Polydictya).

The characters defining the genus were given by Lallemand (1963), i.e., head broad, slightly narrower than the pronotum; frons as long as broad, not carinate, largely rounded dorsally, broadened above clypeus and strongly broader than the latter; vertex at least 4 times broader than long, excavate; tegmina at least 2.5 times longer than broad, densely reticulate; clavus closed with vein $\mathrm{A} 1+\mathrm{A} 2$ extending up to sutural margin; hind wings almost entirely reticulate; anterior tibiae as long as femora, sometimes slightly foliaceous; hind tibiae with 4-6 lateral spines.

\section{Identification key to the species of Polydictya from Sulawesi and neighbouring islands}

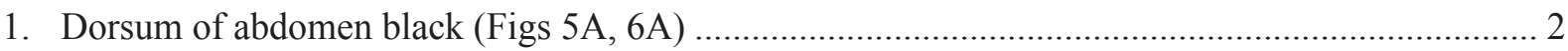

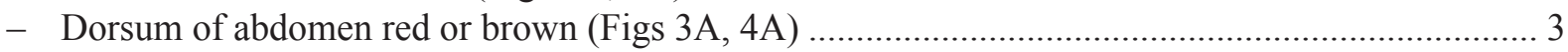

2. Tegmina dark olivaceous brown with small whitish spots along costal margin, claval suture and disc (Fig. 5A); frons and vertex yellow brown (Fig. 5C-D); anterior tibiae slightly laminate (Fig. 5A-B).

Polydictya pelengana sp. nov.

- Tegmina black with irregular white tranverse bands (Fig. 6A); frons and vertex red brown (Fig. 6CD); anterior tibiae slender, not laminate (Fig. 6A-B)

Polydictya thanatos Chew Kea Foo, Porion \& Audibert, 2010

3. Frons and vertex unicolorous (Figs 3C-D, 4C-D)

4

- Frons black-brown with baso-lateral angles yellow brown (Fig. 1C-D)

Polydictya bantimurung sp. nov.

4 Hind wings basally without large bright red patch (Figs 3A, 4A). 5

- Hind wings with a large basal bright red patch (Fig. 2 A). Polydictya basirubra sp. nov.

5. Tegmina nearly unicolorous, brown with a small whitish spot along claval suture and 3 small spots on disc of membrane, no spot along costal margin (Fig. 3A) and not tinged with red ventrally (Fig. 3B); tegmina slightly broader: $\mathrm{LTg} / \mathrm{BTg}=2.72$. Polydictya crassa Distant, 1906

- Tegmina brown, tinged with reddish ventrally (Fig. 4B), and with whitish spots: large one at apex of clavus, 3 along claval suture, 3-4 along costal margin and 3 on disc of membrane (Fig. 4A); tegmina slightly narrower: $\mathrm{LTg} / \mathrm{BTg}=2.86$

Polydictya katsurakoae Nagai \& Porion, 1996 

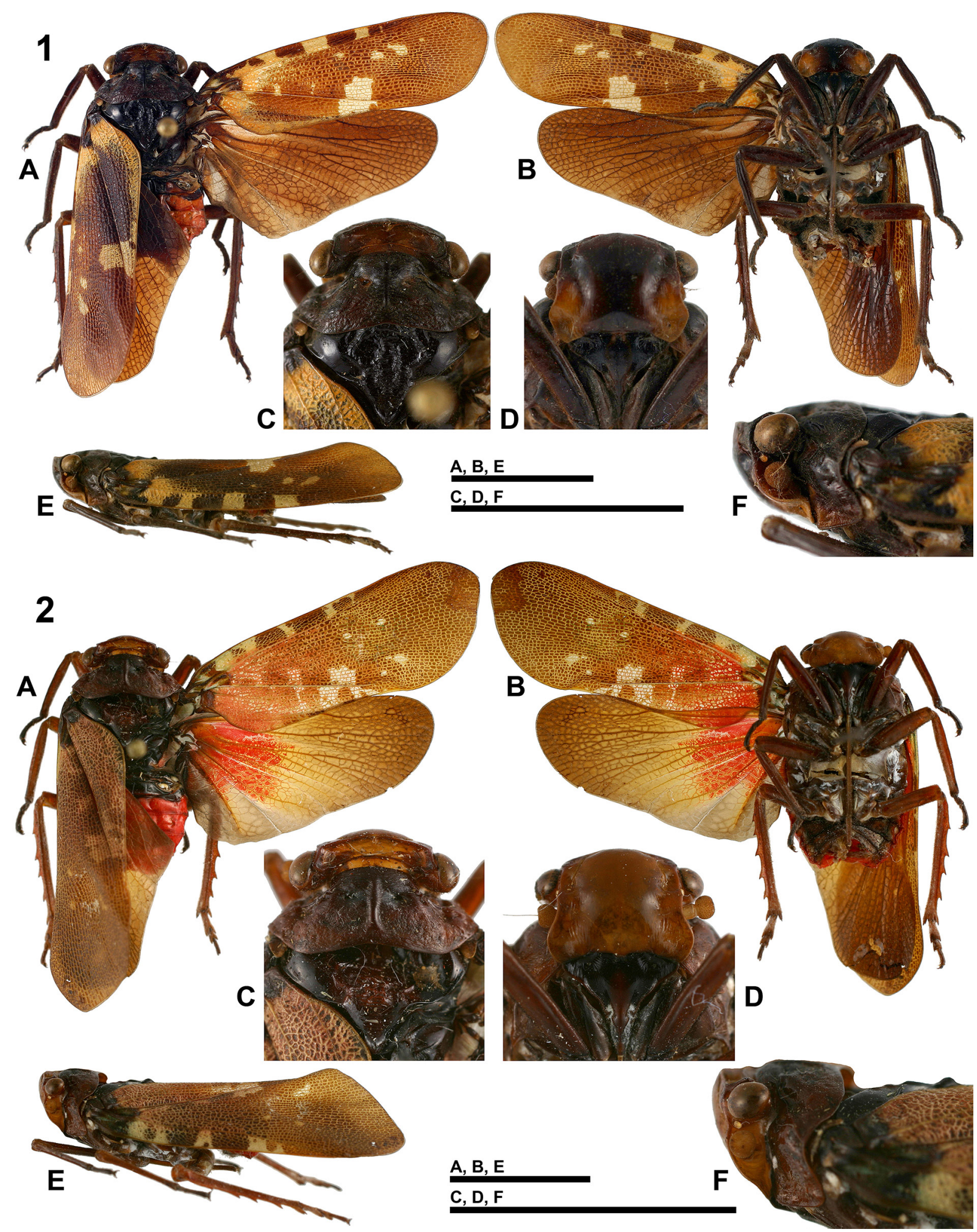

Figs 1-2. 1. Polydictya bantimurung sp. nov. 2. Polydictya basirubra sp. nov. A. Habitus, dorsal view. B. Habitus, ventral view. C. Vertex, pro and mesonotum, dorsal view. D. Frons, normal view. E. Habitus, lateral view. F. Head and prothorax, lateral view. Scale bars $=10 \mathrm{~mm}$. 

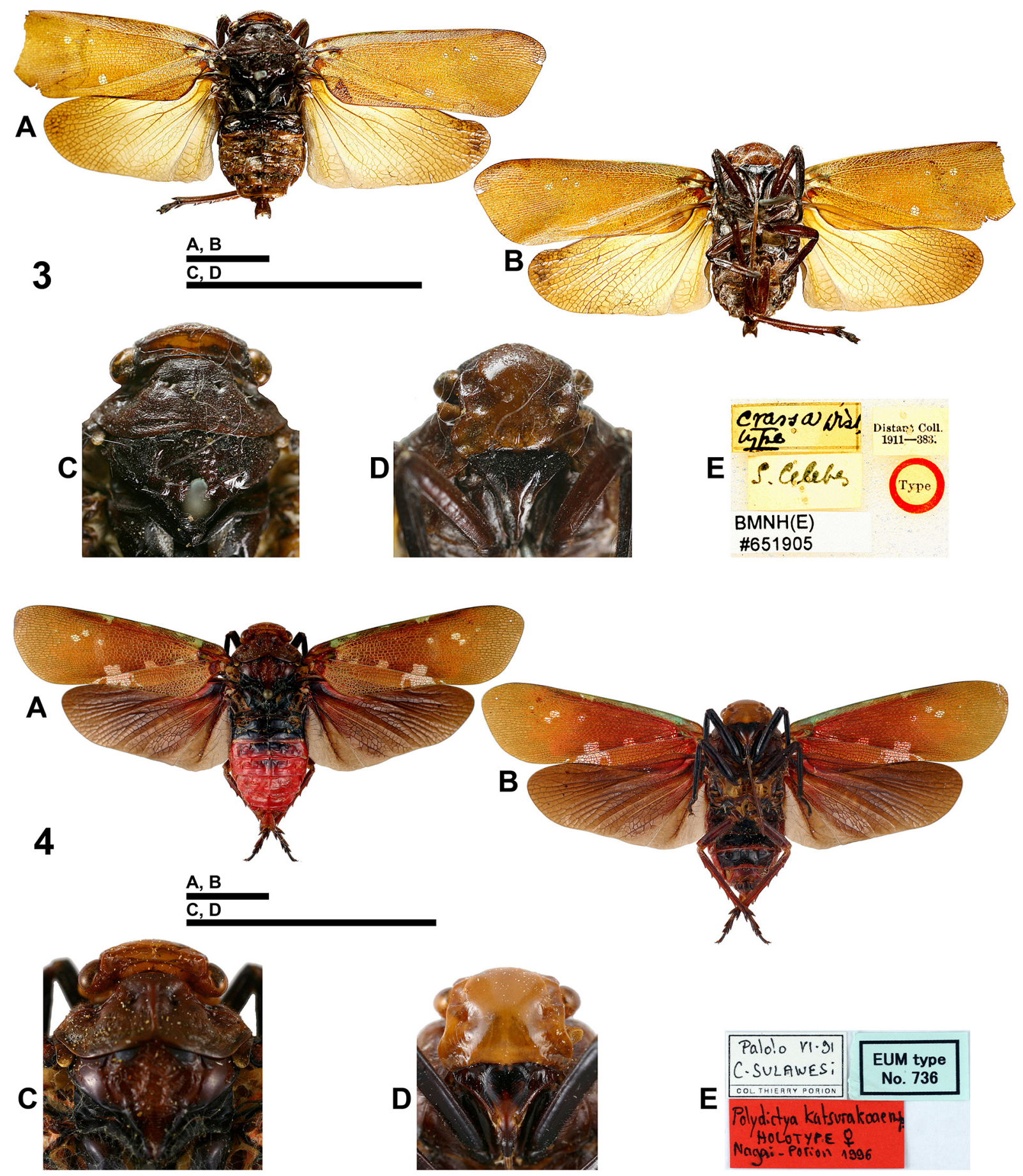

Figs 3-4. 3. Polydictya crassa Distant, 1906. 4. Polydictya katsurakoae Nagai \& Porion, 1996. A. Habitus, dorsal view. B. Habitus, ventral view. C. Vertex, pro and mesonotum, dorsal view. D. Frons, normal view. E. Labels. Scale bars $=10 \mathrm{~mm}$. 

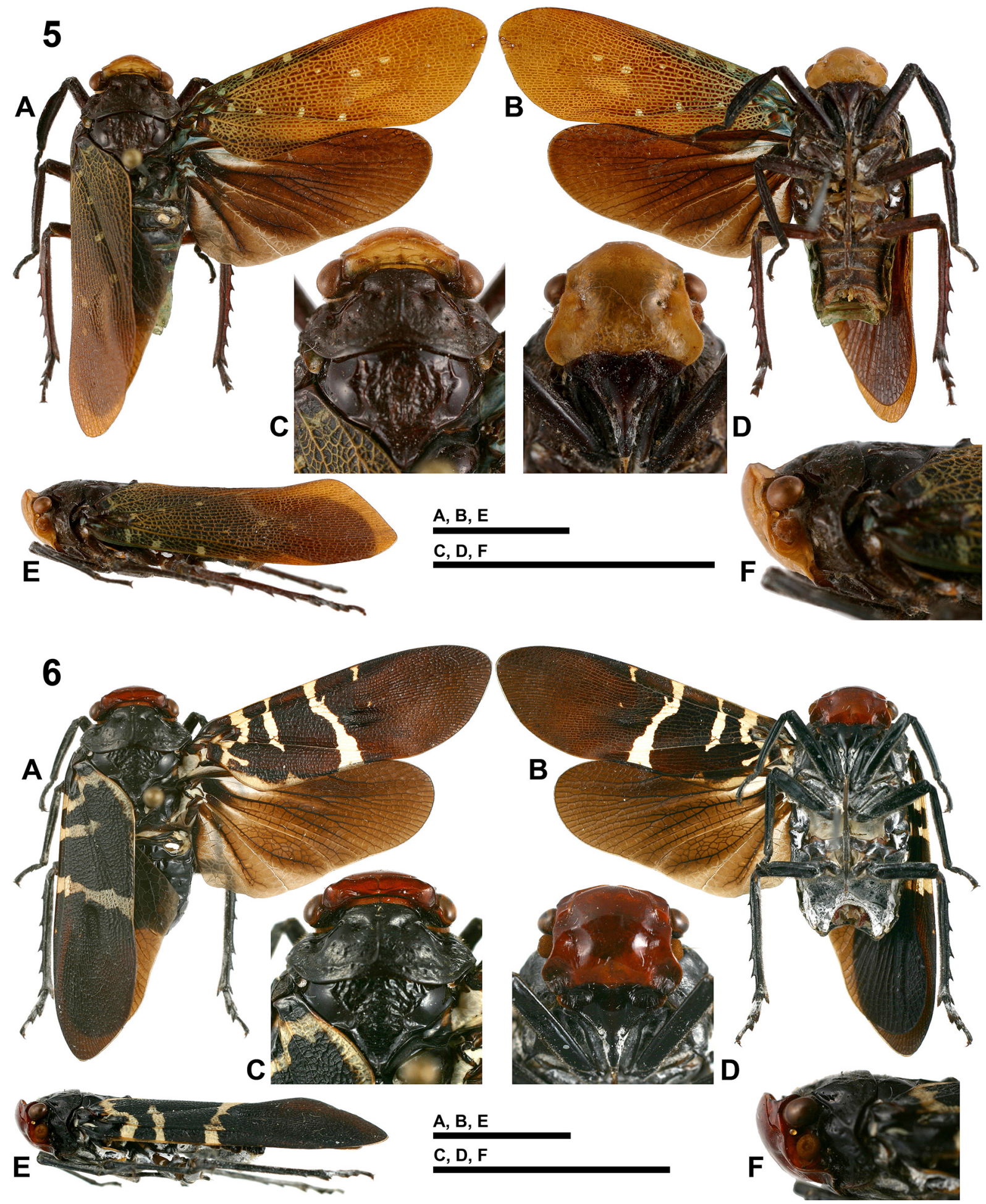

Figs 5-6. 5. Polydictya pelengana sp. nov. 6. Polydictya thanatos Chew Kea Foo, Porion \& Audibert, 2010. A. Habitus, dorsal view. B. Habitus, ventral view. C. Vertex, pro and mesonotum, dorsal view. D. Frons, normal view. E. Habitus, lateral view. F. Head and prothorax, lateral view. Scale bars $=10 \mathrm{~mm}$. 


\section{Polydictya bantimurung sp. nov. urn:1sid:zoobank.org:act:CB4E8FA9-FDC8-4197-AA6E-1E09DCBBF292}

Figs $1,7-8$

\section{Diagnosis}

(1) Tegmina brown, with whitish spots: large one at apex of clavus, 2 small ones along claval suture and 3-4 on disc of membrane; external margin of clavus and 3-4 patches along costal margin, pale greenish yellow (Fig. 1A); (2) hind wings without basal red patch (Fig. 1A); (3) frons regularly rounded in dorsal view, not projecting anteriorly (Fig. 1C), dark brown with ventro-lateral angles yellow-brown (Fig. 1D); (4) anterior tibiae not laminate (Fig. 1A-B); (5) abdomen red dorsally (Fig. 1A); (6) genital segments dark brown.

\section{Etymology}

The species epithet refers to the type location, Bantimurung, and is treated as a noun in apposition.

\section{Type material}

\section{Holotype}

đ: [Coll. I.R.Sc.N.B., Sulawesi, Bantimurung, 454'S 11945'E, Gift J. Constant, I.G.: 32.561] (RBINS).

\section{Paratypes}

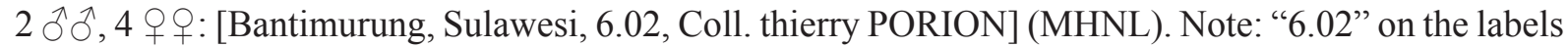
of the paratypes stands for June 2002.

\section{Description}

Measurements and Ratios. LT: $\widehat{\partial}(\mathrm{n}=3): 24.7 \mathrm{~mm}(23.9-25.1)$; 9 ( $\mathrm{n}=4): 29.0 \mathrm{~mm}(28.0-29.5)$; $\mathrm{LTg} /$ $\mathrm{BTg}=3.24 ; \mathrm{BV} / \mathrm{LV}=5.4 ; \mathrm{LF} / \mathrm{BF}=0.70$.

HEAD. Black-brown with ventro-lateral angles of frons yellow-brown (Fig. 1D, F); vertex curved and deeply grooved transversely with lowest point in middle, with all 4 margins carinate (Fig. 1C); frons slightly visible from above (Fig. 1C), convex, smooth, subquadrate with impressed, S-shaped longitudinal groove along lateral margin, starting in front of eye (Fig. 1D); clypeus narrower and shorter than frons, brown apically (Fig. 1D); labium elongate, surpassing coxae (Fig. 1B); antennae yellowbrown with scape cylindrical, elongate; pedicel bulbous (Fig. 1F).

THORAX. Black-brown with lateral pleura of pronotum yellow-brown along ventral margin; mesonotum darker than pronotum (Fig. 1C, F); pro-, meso- and metasternites brown (Fig. 1B); pronotum with transverse wrinkles, longitudinal carina and pair of impressed points on disc; mesonotum smooth with disc wrinkled; scutellum impressed on disc and with apex elevated (Fig. 1C); tegulae dark brown with posterior half yellow-brown (Fig. 1C, F).

Tegmina. (Figs 1A-C). Dark brown with whitish spots on disc: one large, subquadrate at apex of clavus, 2 small ones along claval suture and 3-4 in a longitudinal row near nodal line; external margin of clavus and 3-4 large patches along costal margin, pale greenish yellow; costal and sutural margins subparallel, apex obliquely rounded.

HinD wings. (Fig. 1A-B). Entirely dark brown, broader than tegmina.

Legs. (Fig. 1A-B). All legs dark reddish brown with tarsi I and II darker; tibiae I and II slender; tibiae III with 4-5 lateral and 7 apical spines. 
AвDomen. (Fig. 1A-B). Bright red dorsally with 2 basal tergites black; black-brown ventrally; genital segments dark brown.

Male Genitalia. Pygofer, anal tube and gonostyli dark brown; pygofer higher than long, with posterior margin sinuate in lateral view and showing apically rounded conical process in middle (Fig. 8A-B); anal tube elongate, 2.36 times longer than broad, broader at $2 / 3$ of total length, strongly curved ventrally near base (Fig. 8A-B); lateral margins sinuate (Fig. 8B) and apical margin strongly notched in dorsal view (Fig. 8C); gonostyli (Fig. 8A) elongate with posterior half much broader and strong subbasal constriction in lateral view; strong tooth directed antero-ventrally at half length; apical margin subquadrate; phallic

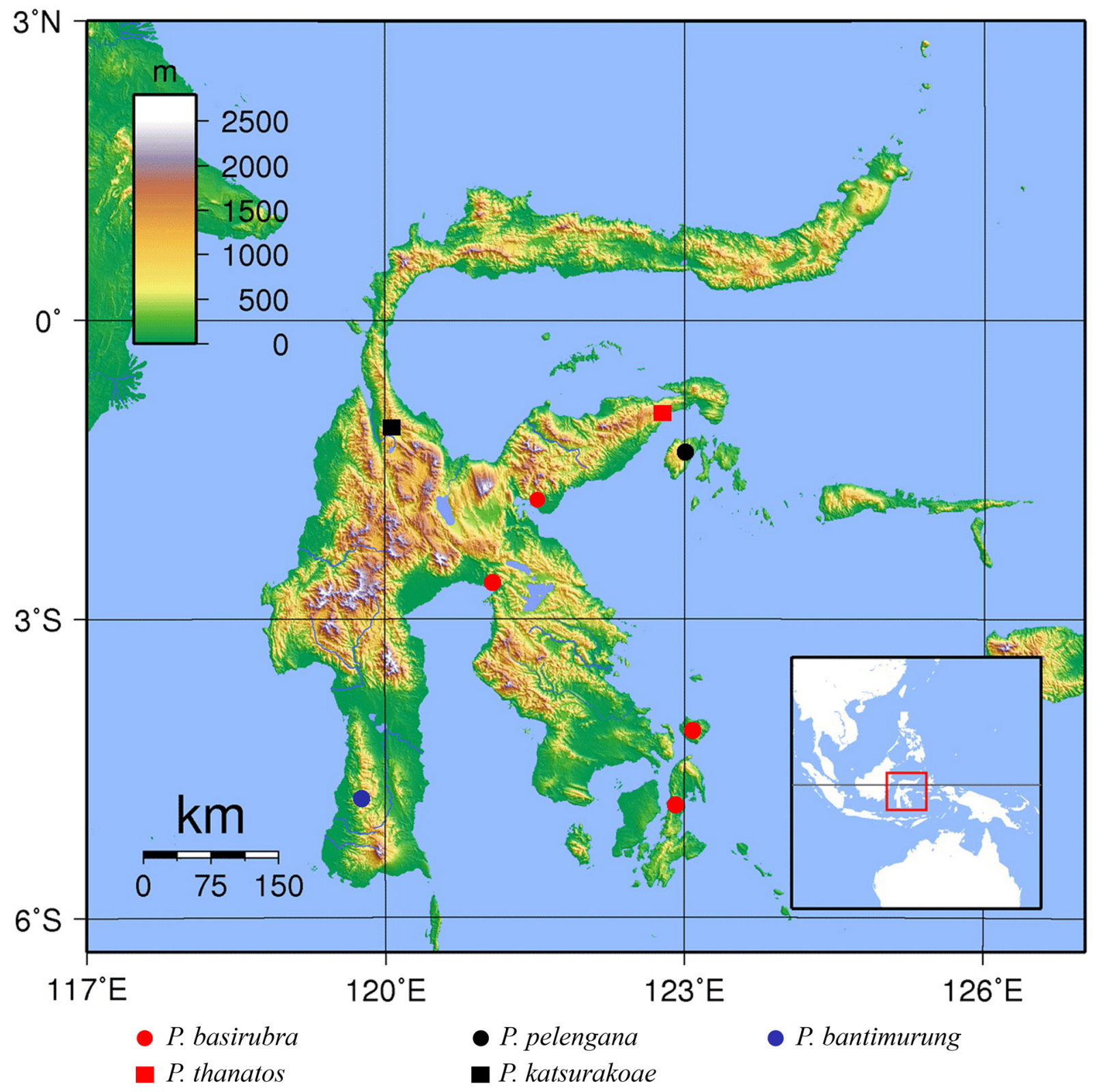

Fig. 7. Distribution map of the species of Polydictya Guérin-Méneville, 1844 of Sulawesi and neighbouring islands. 
complex (Fig. 8D-E) with endosomal process of aedeagus laminate, slightly concave externally, showing irregular dorsal teeth along body, and apex strongly curved dorsally, hook-shaped.

\section{Distribution}

Known from South Sulawesi (Fig. 7).

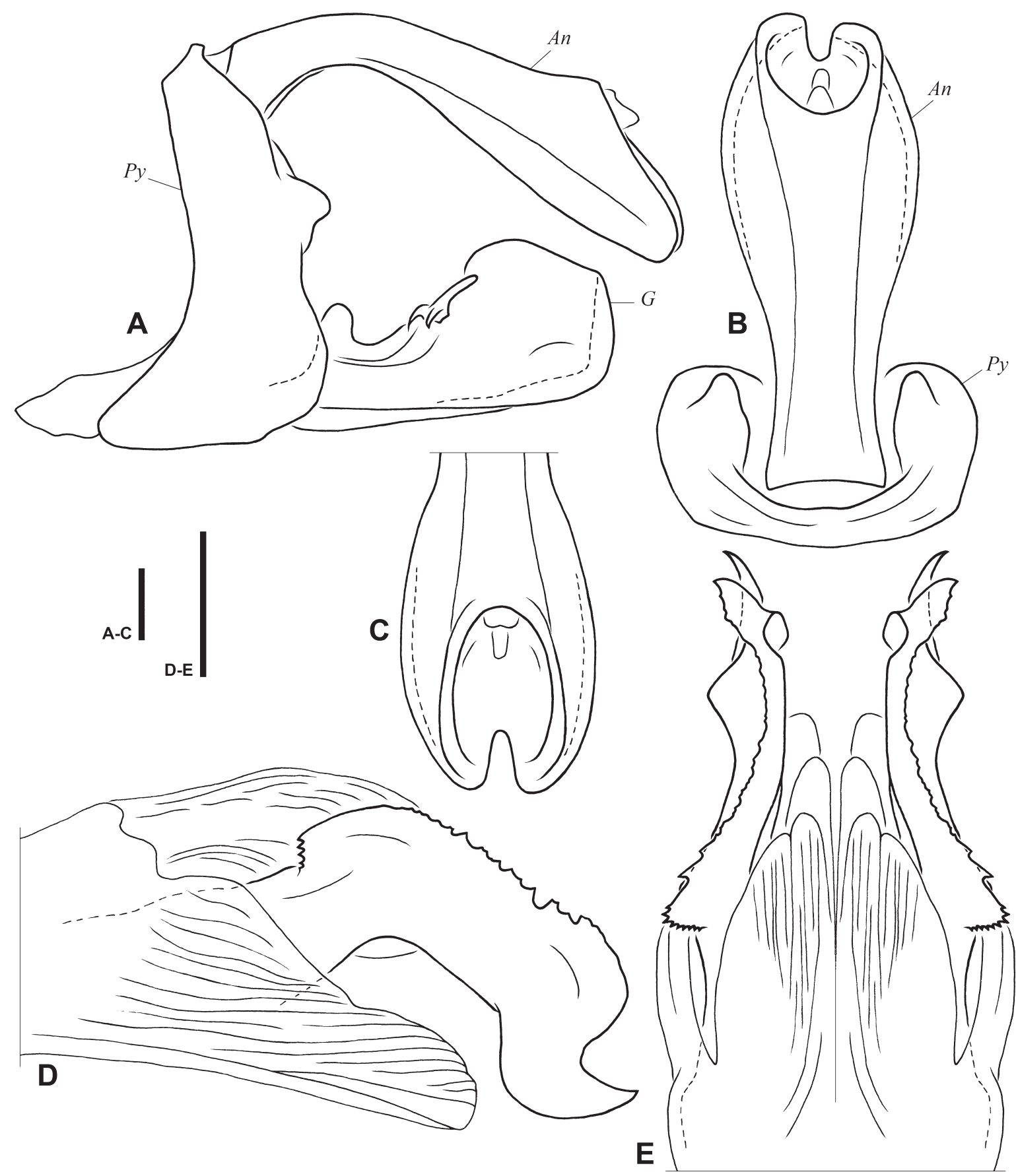

Fig. 8. Polydictya bantimurung sp. nov., ô genitalia. A. Pygofer, anal tube and gonostylus, left lateral view. B. Anal tube and pygofer, dorsal view. C. Apex of anal tube, postero-dorsal view. D. Phallic complex, lateral view. E. Phallic complex, dorsal view. $A n=$ anal tube; $P y=$ pygofer; $G=$ gonostylus. Scale bars $=1 \mathrm{~mm}$. 


\section{Polydictya basirubra sp. nov. urn:1sid:zoobank.org:act:10E93C3A-660E-46B5-B5C6-ECB86F8F62F8}

Figs 2, 7, 9

Polydictya katsurakoae-Nagai \& Porion 2002: 9 (record from Wowoni Island) [erroneous identification].

\section{Diagnosis}

(1) Tegmina brown, tinged with reddish ventrally on basal half (Fig. 2B), and with whitish markings: irregular one at apical half of clavus, 3 along claval suture, 4-5 along costal margin and 3-4 on disc of membrane (Fig. 2A); (2) hind wings with a large basal bright red patch (Fig. 2A); (3) frons regularly rounded in dorsal view, not projecting anteriorly (Fig. 2C), yellow-brown (Fig. 2D); (4) anterior tibiae not laminate (Fig. 2A-B); (5) abdomen red dorsally (Fig. 2A); (6) genital segments red.

\section{Etymology}

The species epithet is formed by the words basis, -is (Latin) = base, and ruber, -bra, -brum (adj., Latin) = red, and refers to the bright red patch at the base of the posterior wing.

\section{Type material}

\section{Holotype}

đ: [Wowoni Island, Indonesie, 09/2001, Coll. Alain Chaminade] (MHNL).

\section{Paratypes}

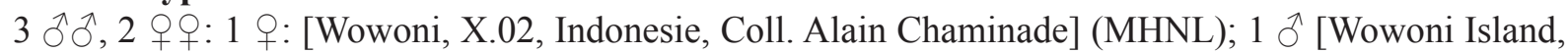
Indonesie, 09/01, Coll. thierry PORION] (MHNL); 1 đో: [Malili, X.95, Sulawesi, Col. Thierry Porion] (MHNL); 1 O: [Buton Island, S.E. Sulawesi, Coll. thierry PORION] [Coll. T. PORION, Muséum de Lyon] (MHNL); 1 đ̃: [Sulawesi Tengah: Nr. Morowali, Ranu River Area, 27.i.-20.iv.1980] [M.J.D. Brendell, B.M. 1980-280] (BMNH).

\section{Coordinates of localities}

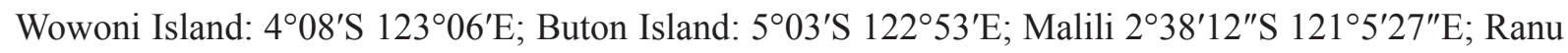
River Area: $1^{\circ} 50^{\prime} 30^{\prime \prime} \mathrm{S} 121^{\circ} 29^{\prime} 30^{\prime \prime} \mathrm{E}$.

\section{Description}

MEASUREMENTS AND RATIOS. LT: $\widehat{o}(\mathrm{n}=3): 26.7 \mathrm{~mm}(25.5-28.3)$; $\uparrow(\mathrm{n}=2$, extrapolated): $30.0-31.1 \mathrm{~mm}$; $\mathrm{LTg} / \mathrm{BTg}=2.61 ; \mathrm{BV} / \mathrm{LV}=6.13 ; \mathrm{LF} / \mathrm{BF}=0.75$.

HEAD. Yellow-brown with clypeus dark brown to black-brown with paler median line (Fig. 2C-D, F); vertex curved with all margins carinate, and deeply grooved with lowest point in middle (Fig. 2C); frons slightly visible from above (Fig. 2C), convex, smooth, subquadrate, with impressed S-shaped longitudinal groove along lateral margin, starting in front of eye (Fig. 2D); clypeus narrower and shorter than frons (Fig. 2D); labium elongate, dark brown, surpassing hind coxae (Fig. 2B); antennae yellowbrown with scape cylindrical, elongate, and pedicel bulbous (Fig. 2D, F).

Thorax. (Fig. 2C, F). Dark brown with pronotum and sometimes disc of mesonotum paler yellowbrown; pronotum coriaceous with smooth median carina and 2 impressed points on anterior half of disc; mesonotum smooth with disc irregularly wrinkled and transverse wrinkles on scutellum; apex of scutellum elevated; tegulae dark brown with apex pale yellow-white.

Tegmina. (Fig. 2A-B, E). Brown with red hue on corium, more conspicuous ventrally; 4 subquadrate to rectangular pale yellow spots along costal margin; irregular yellow-white markings on disc along claval 
joint and on clavus, and 2 spots on disc aligned longitudinally near nodal line; largest spot usually at apex of clavus; tegmina slightly broadening from base to apex and with apex oblique.

HIND wings. (Fig. 2A-B). Brown with antero-basal bright red patch covering about $1 / 4$ of total surface and not reaching posterior margin; broader than tegmina.

Legs. (Fig. 2A-B). All legs reddish-brown; tibiae I and II slender; tibiae III with (4-)5 lateral and 7 apical spines.

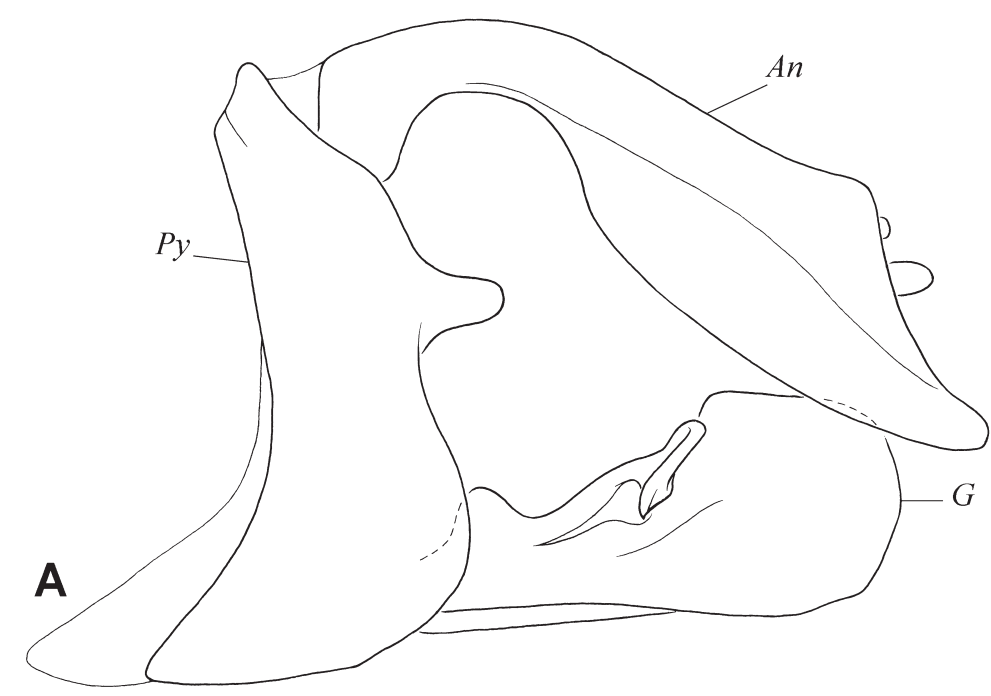

B

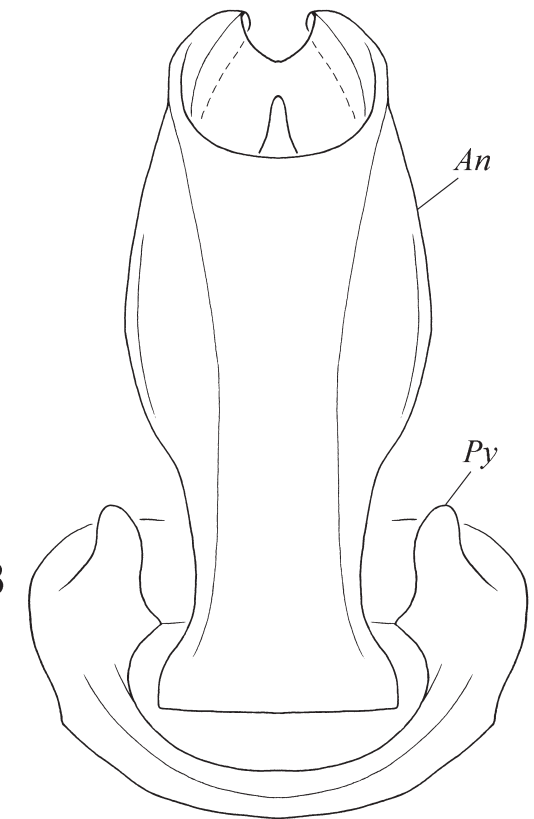

\section{D}
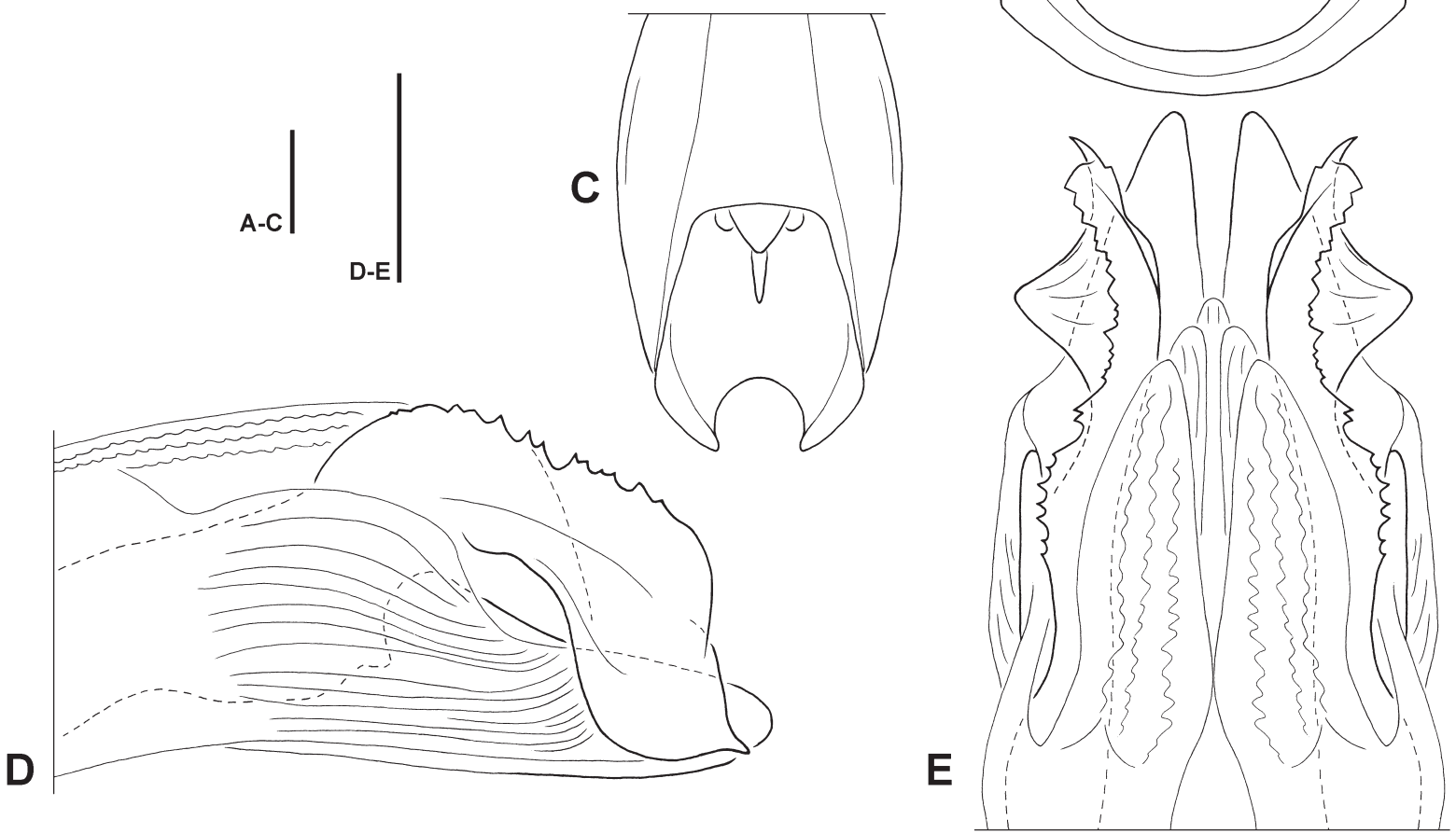

Fig. 9. Polydictya basirubra sp. nov., ô genitalia. A. Pygofer, anal tube and gonostylus, left lateral view. B. Anal tube and pygofer, dorsal view. C. Apex of anal tube, postero-dorsal view. D. Phallic complex, lateral view. E. Phallic complex, dorsal view. $A n=$ anal tube; $P y=$ pygofer; $G=$ gonostylus. Scale bars $=1 \mathrm{~mm}$. 
Aвdomen. (Fig. 2A-B). Bright red with 2 basal tergites black; black ventrally; genital segments bright red.

Male genitalia. Pygofer, anal tube and gonostyli bright red; pygofer higher than long, with posterior margin sinuate in lateral view and showing digitiform process in middle (Fig. 9A-B); anal tube elongate, 2.26 times longer than broad, broader at half of total length, strongly curved ventrally near base (Fig. 9AB); lateral margins sinuate (Fig. 9B) and apical margin strongly notched in dorsal view (Fig. 9C); gonostyli (Fig. 9A) elongate with posterior half much broader and strong subbasal constriction in lateral view; strong tooth directed antero-ventrally at half length; apical margin broadly rounded; phallic complex (Fig. 9D-E) with endosomal process of aedeagus laminate, slightly concave externally and with ventral margin laterally projecting subapically, showing irregular dorsal teeth along body and with apex pointed postero-ventrally.

\section{Distribution}

Known from Central, South and South East (Buton and Wowoni Islands) Sulawesi (Fig. 7).

Polydictya crassa Distant, 1906

Figs 3,7

Polydictya crassa Distant, 1906b: 26 (Type in BMNH).

Polydictya crassa - Schmidt 1912: 72 (comparative note with other Polydictya species). - Metcalf 1947: 86 (catalogued). — Lallemand 1963: 18 (key, description). — Nagai \& Porion 1996: 13; 2004: 31 (listed).

non Polydictya crassa - Nagai \& Porion 2004: 7, pl. 2 fig. 13 (erroneous notes on distribution, illustration of habitus, misidentification of Polydictya pelengana sp. nov.).

\section{Diagnosis}

(1) Tegmina brown with a small, whitish spot along claval suture and 3 small, whitish spots on membrane (Fig. 3A); (2) hind wings without basal red patch (Fig. 3A); (3) frons regularly rounded in dorsal view, not projecting anteriorly (Fig. 3C), brown (Fig. 3D); (4) anterior tibiae slightly laminate (Fig. 3B); (5) abdomen not black dorsally (brown in the single specimen known, but it is possible that the original colour faded due to preservation in a fluid, e.g., ethanol) (Fig. 3A); (6) genital segments brown (same remark as under 5).

\section{Type material examined}

\section{Holotype}

†. [S. Celebes] [crassa Dist. Type] [Distant Coll. 1911-383] [Type] [BMNH(E) \#651905] (BMNH).

\section{Measurements and ratios}

LT (extrapolated): $q(\mathrm{n}=1): 30.0 \mathrm{~mm} ; \mathrm{LTg} / \mathrm{BTg}=2.72 ; \mathrm{BV} / \mathrm{LV}=4.46 ; \mathrm{LF} / \mathrm{BF}=0.79$.

\section{Distribution}

The species was described from southern Sulawesi ("S Celebes") without specific locality.

\section{Polydictya katsurakoae Nagai \& Porion, 1996}

\section{Figs 4, 7}

Polydictya katsurakoae Nagai \& Porion, 1996: 13 (listed), 28 (description), pl. 2, fig. 29 (habitus illustrated).

Polydictya katsurakoae - Chew Kea Foo et al. 2010: 59 (comparative note). 
non Polydictya katsurakoae - Nagai \& Porion 2002: 9 (erroneous record from Wowoni Island based on specimens of $P$. basirubra sp. nov.).

\section{Diagnosis}

(1) Tegmina brown, tinged with reddish ventrally, and with whitish spots: large one at apex of clavus, 3 along claval suture, 3-4 along costal margin and 3 on disc of membrane (Fig. 4A-B); (2) hind wings without basal red patch (Fig. 4A); (3) frons regularly rounded in dorsal view, not projecting anteriorly (Fig. 4C), yellow-brown (Fig. 4D); (4) anterior tibiae not laminate (Fig. 4B); (5) abdomen red dorsally (Fig. 4A); (6) genital segments red.

\section{Type material examined}

\section{Holotype}

O: [Palolo, VI.91, C. Sulawesi, Col. Thierry Porion] [Polydictya kasturakoae n. sp., Holotype ${ }_{+}$, NagaiPorion 1996] [EUM type No. 736] (EUM)

\section{Paratype}

1 ○: [Palolo, VI.91, C. Sulawesi, Indonesia, Col. Thierry Porion] [Polydictya kasturakoae n. sp., Paratype + , Nagai et Porion 1994] (MHNL).

\section{Coordinates of type locality}

Palolo: 1³9'S 11954’E.

\section{Notes}

The holotype and paratype were erroneously stated to be males in the original description (Nagai \& Porion 1996).

Nagai \& Porion (1996) stated that the paratype was deposited in MNHN but it is currently in MHNL as most specimens of Thierry Porion's collection.

\section{Measurements and ratios}

LT (extrapolated): ㅇ $(\mathrm{n}=2): 31.2-31.6 \mathrm{~mm} ; \mathrm{LTg} / \mathrm{BTg}=2.86 ; \mathrm{BV} / \mathrm{LV}=7.56 ; \mathrm{LF} / \mathrm{BF}=0.72$.

\section{Distribution}

Known from Central Sulawesi (Fig. 7).

Polydictya pelengana sp. nov. urn:1sid:zoobank.org:act:CD1E96F8-8487-4ED1-BC2F-820CC17B37CA

Figs $5,7,10$

Polydictya crassa - Nagai \& Porion 2004: 7 (notes), pl. 2 fig. 13 (habitus illustrated) [erroneous identification].

\section{Diagnosis}

(1) Tegmina dark olivaceous brown with small, whitish spots: 2-4 along claval suture, 4 along costal margin and 2 on disc of membrane (Fig. 5A); (2) hind wings without basal red patch (Fig. 5A); (3) frons slightly projecting anteriorly in dorsal view (Fig. 5C), yellow-brown (Fig. 5D); (4) anterior tibiae slightly laminate externally (Fig. 5A-B); (5) abdomen black dorsally (Fig. 5A); (6) genital segments black.

\section{Etymology}

The species epithet refers to the type locality, Peleng Island. 


\section{Type material}

\section{Holotype}

đ: [Coll. I.R.Sc.N.B., Indonesia, Peleng Is1., iii.2004, exchange S. Jakl, I.G.: 31.970] (RBINS).

\section{Paratypes}

1 ภ, 5 우: 1 ภ: same data as holotype (RBINS); 1 ㅇ: [Coll. I.R.Sc.N.B., Indonesia, Peleng Isl., ix.2012, gift from B. Kneubühler, I.G.: 32.427] (RBINS); $1 \overbrace{}^{\Uparrow}$ : [Peleng, Apr. 2003] (MHNL); 1 đ̊: [Peleng, 3.03,

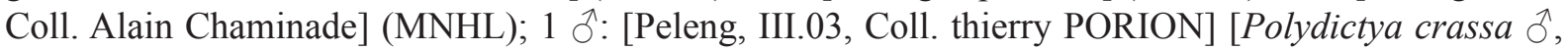
Coll. thierry Porion] (MHNL); 1 § : [Peleng, III.03, Coll. thierry PORION] (MHNL); 1 đ: [Peleng Isld, 3.03, Coll. thierry PORION] (MHNL). Note: "3.03" and "III.03" on the labels of the paratypes stand for March 2003.

\section{Coordinates of type locality}

Peleng Island: $1^{\circ} 24^{\prime} \mathrm{S} 123^{\circ} 10^{\prime} \mathrm{E}$.

\section{Description}

Measurements and ratios. LT: $\widehat{O}(\mathrm{n}=5): 28.7 \mathrm{~mm}(27.2-30.0)$; $q(\mathrm{n}=1): 29.7 \mathrm{~mm}$; $\mathrm{LTg} / \mathrm{BTg}=2.80$; $\mathrm{BV} / \mathrm{LV}=4.57 ; \mathrm{LF} / \mathrm{BF}=0.71$.

HEAD. Pale yellow-brown (Fig. 5C-D); vertex strongly curved and deeply grooved with lowest point in middle and with all margins carinate (Fig. 5C); frons slightly visible from above (Fig. 5C), strongly convex, smooth, subquadrate with sides projecting laterally basally and with impressed C-shaped groove along lateral margin, starting in front of eye (Fig. 5D); clypeus subtriangular, narrower and shorter than frons, black-brown (Fig. 5D); labium elongate, black-brown, surpassing hind coxae (Fig. 5B); antennae pale yellow-brown with scape cylindrical, slightly elongate and pedicel strongly bulbous (Fig. 5D, F).

Thorax. (Fig. 5C, F). Dark brown to black-brown; pronotum irregularly wrinkled with smooth longitudinal carina and 2 strongly impressed points on anterior half of disc; mesonotum with disc wrinkled and sides smooth; scutellum impressed basally, elevated apically and slightly transversely winkled; tegulae brown with apex pale yellow-brown.

Tegmina. (Fig. 5A-B, E). Dark brown to black-brown with olivaceous green hue on basal half, more conspicuous ventrally; veins and veinlets yellow-brown, maybe olivaceous green in living specimens; 3-4 small, yellow-white spots along costal margin, $2-4$ along claval joint and 2 longitudinally aligned on disc near nodal line; costal and sutural margin subparallel; apex oblique with apico-sutural angle broadly rounded.

HIND wINGS. (Fig. 5A-B). Dark brown to black-brown with a basal milky-white elongate patch along costal vein; broader than tegmina.

Legs. (Fig. 5A-B). Dark reddish brown to nearly black; anterior legs darker; tibiae I slightly foliaceous externally; tibiae II slender; tibiae III with 4-5 lateral and 7 apical spines.

AbDomen. (Fig. 5A-B). Tergites black with membranous joints greenish; sternites brown; genital segments black-brown.

Male Genitalia. Pygofer, anal tube and gonostyli black-brown; pygofer higher than long, with posterior margin sinuate in lateral view (Fig. 10A-B); anal tube elongate, 1.95 times longer than broad, broader at $3 / 5$ of total length, strongly curved ventrally near base (Fig. 10A-B); lateral margins sinuate (Fig. 10A) and apical margin excavate in dorsal view (Fig. 10C); gonostyli (Fig. 10A) elongate with posterior half broader and strong subbasal constriction in lateral view; strong tooth directed antero-ventrally at half length; apical margin rounded; phallic complex (Fig. 10D-E) with endosomal process of aedeagus laminate, 
slightly concave externally and with ventral margin laterally projecting subbasally; dorsal margin rounded in lateral view and nearly smooth, showing few slightly marked teeth near base and near apex.

\section{Distribution}

Known from Peleng Island off Central Sulawesi (see map Fig. 7).
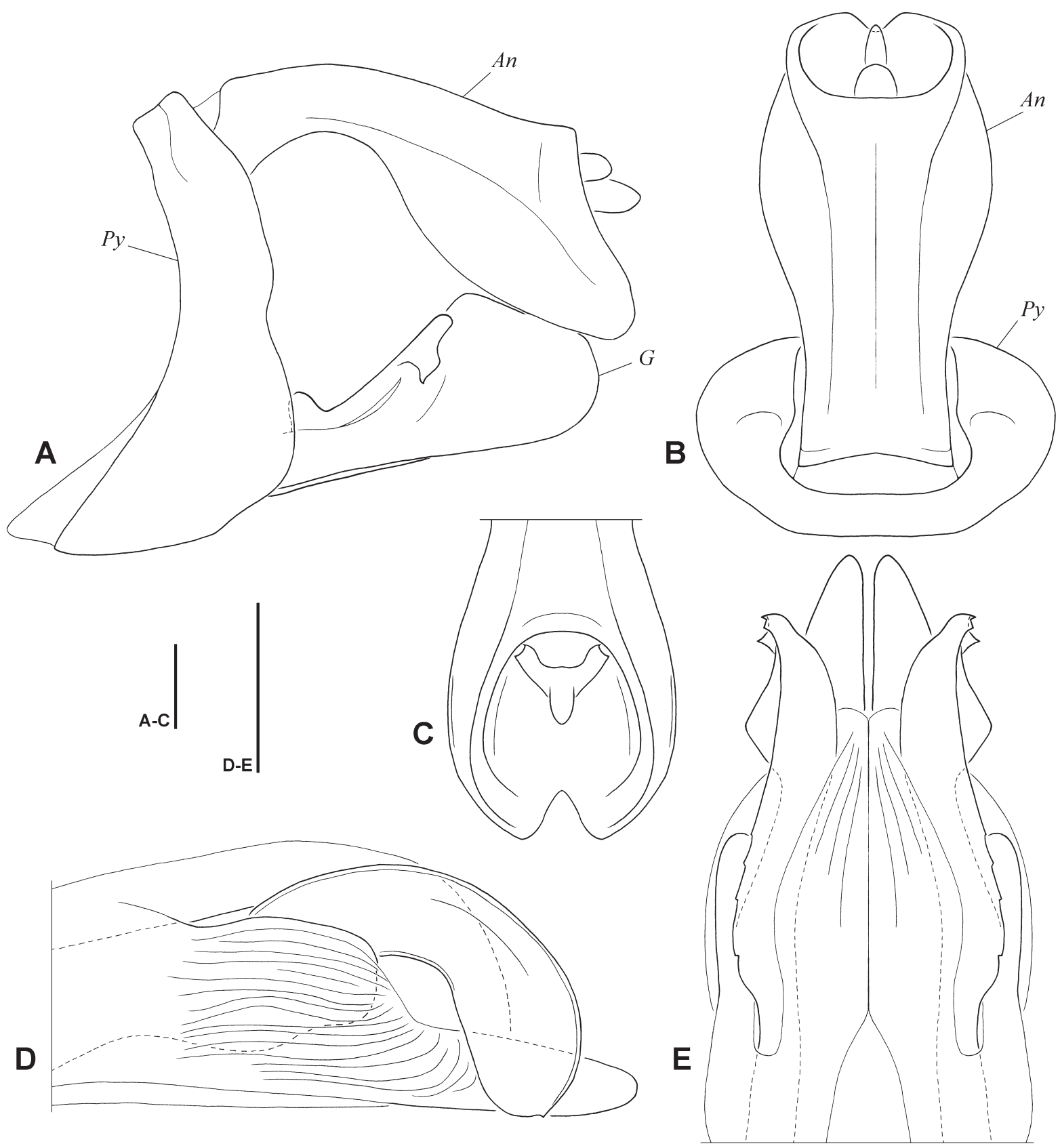

Fig. 10. Polydictya pelengana sp. nov., ô genitalia. A. Pygofer, anal tube and gonostylus, left lateral view. B. Anal tube and pygofer, dorsal view. C. Apex of anal tube, postero-dorsal view. D. Phallic complex, lateral view. E. Phallic complex, dorsal view. $A n=$ anal tube; $P y=$ pygofer; $G=$ gonostylus. Scale bars $=1 \mathrm{~mm}$. 
Polydictya thanatos Chew Kea Foo, Porion \& Audibert, 2010

Figs 6, 7, 11 .

Polydictya thanatos Chew Kea Foo, Porion \& Audibert, 2010: 59 (described); pl. 4 figs 1-3 (habitus and details of head).

\section{Diagnosis}

(1) Tegmina black with 3 irregular transverse white bands before apex of clavus, one small, white line on costal cell at nodal line, and scutellar margin of clavus whitish (Fig. 6A); (2) hind wings without
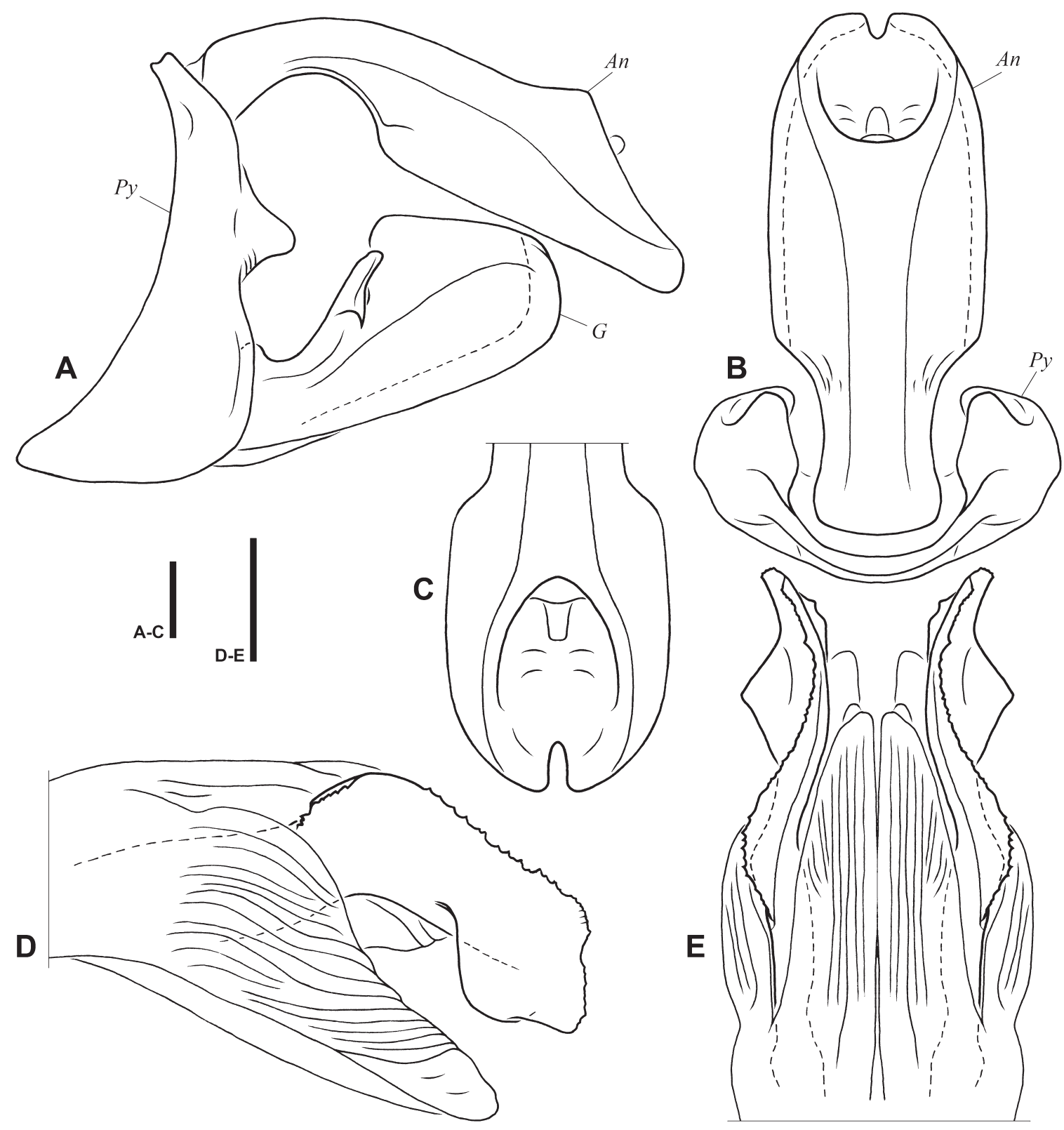

Fig. 11. Polydictya thanatos Chew Kea Foo, Porion \& Audibert, 2010, male genitalia. A. Pygofer, anal tube and gonostylus, left lateral view. B. Anal tube and pygofer, dorsal view. C. Apex of anal tube, postero-dorsal view. D. Phallic complex, lateral view. E. Phallic complex, dorsal view. $A n=$ anal tube; $P y=$ pygofer; $G=$ gonostylus. Scale bars $=1 \mathrm{~mm}$. 
basal red patch (Fig. 6A); (3) frons regularly rounded in dorsal view, not projecting anteriorly (Fig. 6C), dark red (Fig. 6D); (4) anterior tibiae not laminate (Fig. 6A-B); (5) abdomen black dorsally (Fig. 6A); (6) genital segments black.

\section{Type material examined}

\section{Holotype}

J: [C.E. Sulawesi, 15 Kms E. Luwuk, 300-600 m IV-2008] [Polydictya thanatos n. sp. S. Chew et T. Porion 2009, Holotype ${ }^{\Uparrow}$ ] [Coll. Porion, 2010.54, Muséum de Lyon] (MHNL).

\section{Paratype}

1 đ [Indonesie, E-Sulawesi, Luwuk, 2.2009] [Polydictya thanatos n. sp. Paratype Mâle, S. Chew et T. Porion 2009] [Museum Paris MNHN (EH) 17722] (MNHN).

\section{Coordinates of type locality}

Luwuk: 055'48.32”'S 12247’45.96”'E

\section{Note}

The description (Chew Kea Foo et al. 2010) mentions three more paratypes (two in Stanislav Jakl's collection and one in Thierry Porion's), which were not examined in the present study.

\section{Measurements and ratios}

$\mathrm{LT}: \widehat{\jmath}(\mathrm{n}=1): 27.5 \mathrm{~mm} ; \mathrm{LTg} / \mathrm{BTg}=2.93 ; \mathrm{BV} / \mathrm{LV}=6.25 ; \mathrm{LF} / \mathrm{BF}=0.79$.

\section{Male genitalia}

Pygofer, anal tube and gonostyli black; pygofer higher than long, with posterior margin sinuate in lateral view and showing digitiform process in middle (Fig. 11A-B); anal tube elongate, 2.35 times longer than broad, strongly curved ventrally near base (Fig. 11A-B); sides subparallel on half of length in middle (Fig. 11B), apical margin notched in dorsal view (Fig. 11C); gonostyli (Fig. 11A) elongate with posterior half broader and strong subbasal constriction in lateral view; strong tooth directed antero-ventrally at half length; apical margin rounded; phallic complex (Fig. 11D-E) with endosomal process of aedeagus laminate, slightly concave externally and with ventral margin ventro-laterally projecting subapically; dorsal margin slightly curved laterally near base with irregular teeth, straight in lateral view and showing irregular teeth to apex; sinuate in dorsal view.

\section{Distribution}

Known from Central Sulawesi (Fig. 7).

\section{Discussion}

Considering that five of the six species of Polydictya from Sulawesi were described in the last twenty years, it seems likely that more species await discovery. The distribution map shows that large areas within Sulawesi and a number of neighbouring islands remain unexplored in terms of Polydictya. More field work should be conducted in those areas to document the insect fauna and make observations on the host-plants and biology of those insects. Although they are actively searched for by collectors, the feeding habits, larval stages and eggs remain unknown for all species treated in the present paper.

\section{Acknowledgements}

I thank all the curators listed above for the access to the material under their responsibility, Messrs Cédric Audibert, Joël Clary and Harold Labrique for their kindness and help during my visit at MHNL and Messrs Mick Webb and Max Barclay during my visit at BMNH. This study has benefitted from 
funds from the European Union (Synthesys Project - Grant GB-TAF-1642) for a visit to the collection of BMNH in 2011 and from MHNL for a visit to its collections. I also thank my colleagues, Dr Patrick Grootaert and Mr Pol Limbourg (RBINS), and Prof. Thierry Bourgoin (MNHN) for their permanent support, Mr Thierry Porion for interesting discussions and Mrs Megan M. Critser for reviewing the language.

\section{References}

Atkinson E.T. 1885. Notes on Indian Rhynchota. No. 4. Journal of the Asiatic Society of Bengal 54: 127-158. Available from http://hemiptera-databases.org/flowpdf/644.pdf [accessed 7 Nov. 2014]

Bourgoin T. 2014. FLOW (Fulgoromorpha Lists on The Web): A world knowledge base dedicated to Fulgoromorpha. V.8, updated [2 Sep. 2014]. Available from http://hemiptera-databases.org/flow/ [accessed 7 Nov. 2014]

Chew Kea Foo S., Porion T. \& Audibert C. 2010. Cinq nouveaux Fulgoridae asiatiques (Hemiptera : Fulgoromorpha). Les cahiers du Musée des Confluences - Etudes scientifiques 1: 51-64.

Constant J. 2004. Révision des Eurybrachidae (I). Le genre Amychodes Karsch, 1895 (Homoptera: Fulgoromorpha: Eurybrachidae). Bulletin de l'Institut royal des Sciences naturelles de Belgique 74: $11-28$.

Constant J. 2009. A new species of Polydictya from Sumatra and notes on P. chantrainei Nagai et Porion, 2004 (Hemiptera: Fulgoromorpha: Fulgoridae). Annales zoologici 59 (3): 293-296. http:// dx.doi.org/10.3161/000345409X476378

Constant J. 2010. A new species of Polydictya from Lombok (Hemiptera, Fulgoromorpha, Fulgoridae). Nouvelle Revue d'Entomologie 26 (2) (2009): 155-161.

Constant J. \& Pham H.T. 2008. A new species of Polydictya from Vietnam (Hemiptera, Fulgoromorpha, Fulgoridae). Nouvelle Revue d'Entomologie (N.S.) 25 (1): 27-31.

Distant W.L. 1888. An enumeration of the Rhynchota received from Baron von Müller, and collected by Mr. Sayer in New Guinea during Mr. Cuthbertson's expedition. Transactions of the Entomological Society of London 1888: 475-489. http://dx.doi.org/10.1111/j.1365-2311.1888.tb01315.x

Distant W.L. 1906a. The fauna of British India, including Ceylon and Burma. Rhynchota. Vol. 3. Taylor \& Francis, London. http://dx.doi.org/10.5962/bhl.title.48423

Distant W.L. 1906b. Rhynchotal notes xxxviii. Annals and Magazine of Natural History (ser. 7) 18: 18-32. Available from http://biodiversitylibrary.org/page/19366260 [accessed 7 Nov. 2014]

Gerstaecker C.E.A. 1895. Ueber einige bemerkenswerthe Fulgorinen der Greifswalder zoologischen Sammlung. Mittheilungen aus dem Naturwissenschaftlichen Verein für Neu-Vorpommern und Rügen 27: $1-50$.

Guérin-Méneville F.E. 1844. Insectes. In: Cuvier G.L.C.F.D. Iconographie du règne animal. http:// dx.doi.org/10.5962/bhl.title.10331

Jacobi A. 1910. 12. Hemiptera. 7. Homoptera. In: Sjöstedt Y. (ed.) Wissenschaftliche ergebnisse der Schwedischen Zoologischen Expedition nach dem Kilimandjaro, dem Meru und den Umgebenden Massaisteppen Deutsch-Ostafrikas 1905-1906, unter leitung von Prof. Dr. Yngve Sjöstedt. Vol. 2: 97136. P. Palmquists aktiebolag, Stockholm. http://dx.doi.org/10.5962/bhl.title.1805

Karsch F.A.F. 1890. Afrikanische Fulgoriden. Berliner Entomologische Zeitschrift 35 (1): 57-70. http:// dx.doi.org/10.1002/mmnd.18900350105 
Kirkaldy G.W. 1902. Memoirs on Oriental Rhynchota. The Journal of the Bombay Natural History Society 14: 46-58. Available from http://biodiversitylibrary.org/page/30157663 [accessed 7 Nov. 2014]

Krikaldy G.W. 1907. "Current criticism." The Entomologist 40: 58-60. Available from http:// biodiversitylibrary.org/page/11406497 [accessed 7 Nov. 2014]

Lallemand V. 1959. Révision des espèces africaines de la famille Fulgoridae (Super-famille Fulgoroides - sous-ordre des Homoptères). Publicaçoes culturais da companhia de diamantes de Angola 41: 37-124.

Lallemand V. 1963. Révision des Fulgoridae (Homoptera). Deuxième partie. Faunes asiatique et australienne. Mémoires de l'Institut royal des Sciences naturelles de Belgique (2e série) 75, Institut royal des Sciences naturelles de Belgique, Brussels.

Melichar L. 1903. Homopteren-Fauna von Ceylon. F. L. Dames, Berlin. Available from http://ag.udel. edu/research/delphacid/documents/Melichar1903-Ceylon.pdf [accessed 7 Nov. 2014]

Metcalf Z.P. 1947. General Catalogue of the Homoptera. Fascicle IV. Fulgoroidea. Part. 9. Fulgoridae. North Carolina State College, Raleigh (U.S.A.).

Nagai S. \& Porion T. 1996. Fulgoridae 2: Catalogue illustré des faunes asiatique et australienne. Sciences Nat, Compiègne.

Nagai S. \& Porion T. 2002. Fulgoridae 2. Supplement 1. New Fulgoridae from South-East Asia. Hillside Books, Canterbury.

Nagai S. \& Porion T. 2004. Fulgoridae 2. supplement 2. Nouveaux Fulgoridae d'Asie du Sud-Est. Hillside Books, Canterbury.

Schmidt E. 1907. Beitrag zur Kenntnis der Fulgoriden. Die Arten des Genus Myrilla Distant. Stettiner Entomologische Zeitung 68: 113-116. Available from http://hemiptera-databases.org/flowpdf/957.pdf [accessed 7 Nov. 2014]

Schmidt E. 1912. Diagnosen neuer Fulgoriden-Gattungen und Arten nebst einigen Bemerkungen. Stettiner Entomologische Zeitung 73: 67-102. Available from http://biodiversitylibrary.org/page/8824601 [accessed 7 Nov. 2014]

Stål C. 1866. Hemiptera Africana. Vol. 4. Hemiptera Homoptera Latr. Ex officina Norstedtiana, Stockholm. http://dx.doi.org/10.5962/bhl.title.8566

Walker F. 1851. List of the specimens of Homopterous insects in the collection of the British Museum. Part.2. British Museum (Natural History), London. http://dx.doi.org/10.5962/bhl.title.9063

Manuscript received: 12 June 2014

Manuscript accepted: 16 September 2014

Published on: 26 January 2015

Topic editor: Koen Martens

Desk editor: Charlotte Thionois

Printed versions of all papers are also deposited in the libraries of the institutes that are members of the EJT consortium: Muséum national d'Histoire naturelle, Paris, France; Botanic Garden Meise, Belgium; Royal Museum for Central Africa, Tervuren, Belgium; Natural History Museum, London, United Kingdom; Royal Belgian Institute of Natural Sciences, Brussels, Belgium; Natural History Museum of Denmark, Copenhagen, Denmark. 